\title{
PENGARUH PENAMBAHAN BUBUR DAUN KEMANGI ( Ocimim basilicum L. ) TERHADAP KANDUNGAN GIZI KERUPUK SAGU
}

\section{EFFECT OF ADDITION OF BASIL (Ocimim basilicum L.) LEAF PORRIDGE TO NUTRITIONAL CONTENT OF SAGO CRACKERS}

\author{
Hijra Wijaraya N 1), Muh. Wiharto Caronge ${ }^{2)}$, Muh. Rais ${ }^{3)}$ \\ ${ }_{1}^{1}$ Alumni Program Studi Pendidikan Teknologi Pertanian \\ ${ }^{2}$ dan ${ }^{3}$ Dosen PTP FT UNM \\ ijaa0611@gmail.com
}

\begin{abstract}
ABSTRAK
Tujuan penelitian ini adalah untuk mengetahui pengaruh penambahan bubur daun kemangi terhadap kandungan gizi kerupuk sagu. Rancangan percobaan yang digunakan adalah Rancangan Acak Lengkap (RAL) yang terdiri dari konsentrasi penambahan bubur daun kemangi, yaitu: $0 \%$ (Kontrol), 10\%, 15\%, dan 20\%. Parameter yang diamati dalam penelitian ini adalah analisis kimia (kadar air, kadar provitamin A ( $\beta$-karoten), kandungan fosfor, kandungan antioksidan) dan nilai organoleptik kerupuk sagu. Hasil penelitian menunjukkan bahwa penambahan konsentrasi bubur daun kemangi mempengaruhi kadar air, kadar provitamin $A$, khususnya $\beta$-karoten, kadar fosfor, dan tingkat antioksidan kerupuk sagu. Begitu juga pada hasil penerimaan atau tingkat kesukaan panelis. Perlakuan terbaik, dalam hal analisis kimia dan uji organoleptik, adalah kerupuk sagu dengan penambahan 10\% konsentrasi penambahan bubur daun kemangi, dengan nilai kadar air 7,96\%, kadar provitamin A ( $\beta$-karoten) sebesar 1,96 \%, kadar fosfor $0,045 \%$, dan kandungan antioksidan 3,98\%, nilai kesukaan warna 3,23, nilai kesukaan aroma 3,65, nilai kesukaan rasa 3,87, dan nilai kesukaan tekstur 3,93.
\end{abstract}

Kata kunci : Kerupuk sagu, bubur daun kemangi, organoleptik, analisis kimia

\section{ABSTRACT}

The purpose of this study was to determine the effect adding gruel of basil leave to the nutritional content of sago crackers. The experimental design used was a Completely Randomized Design (CRD) consisting of the concentration of the adding gruel of basil leave, namely: $0 \%$ (Control), $10 \%, 15 \%$, and $20 \%$. The parameters observed in this study were chemical analysis (water content, levels of provitamin A ( $\beta$-carotene), phosphorus content, antioxidant content) and organoleptic value of sago crackers. The results showed that the concentration of adding gruel of basil leave affect water content, levels of provitamin $A$, especially $\beta$-carotene, phosphorus levels, and antioxidant levels of sago crackers. Likewise, on the results of acceptance or the level of panelist fondness. The best treatment, in terms of chemical analysis and organoleptic test, is sago crackers with the addition of $10 \%$ concentration of adding gruel of basil leave, with a value water content of $7.96 \%$, provitamin A content ( $\beta$-carotene) level of $1.96 \%$, phosphorus content of $0.045 \%$, and $3.98 \%$ antioxidant content, fondness value of color 3.23 , fondness value of aroma 3.65 , fondness value of flavour 3.87, and fondness value of texture 3.93.

Keywords: sago crackers, gruel of basil leave, organoleptic, chemical analysis 


\section{PENDAHULUAN}

Sagu sangat potensial untuk dikembangkan sebagai bahan pangan alternatif bagi masyarakat Indonesia selain beras, karena kandungan karbohidrat sagu mampu menghasilkan pati kering hingga 25 ton per $\mathrm{Ha}$, kemampuan subtitusi tepung dalam industri pangan, peluang meningkatkan produktivitas, potensi areal dan perluasannya, serta kemungkinan diversifikasi produk (Alfons dan Bustaman, 2005). Dengan demikian, prospek dan peluang pengembangan sagu baik sebagai bahan pangan maupun sebagai bahan baku industri cukup menjanjikan. Menurut Richana dkk., (2000) dalam $100 \mathrm{~g}$ pati sagu mengandung $94 \mathrm{~g}$ karbohidrat dan $0,2 \mathrm{~g}$ protein.

Sagu merupakan pangan utama sejak zaman dahulu bagi sebagian masyarakat Indonesia seperti penduduk di Papua dan Maluku, dan sebagian masyarakat di Sulawesi seperti Kendari dan Luwu (Palopo). Demikian pula, pemanfaatan sagu untuk pembuatan makanan tradisional sudah lama dikenal oleh penduduk di daerah-daerah penghasil sagu baik di Indonesia maupun di Papua Nugini dan Malaysia (Boston, 2009). Sagu dapat dimanfaatkan sebagai bahan pangan setelah berbentuk tepung dan digunakan pada berbagai jenis olahan makanan antara lain papeda maupun kapurung dimana fungsi kedua makanan tersebut hanyalah sebagai makanan selingan saja (PKPP, 2012).

Sagu juga digunakan untuk bahan pangan yang lebih komersial seperti roti, biskuit, sohun, kerupuk, bihun, dan sebagainya (Auliah, 2012). Menurut Peningkatan Kemampuan Peneliti dan Perekayasa (PKPP) (2012) teknologi pengolahan yang berkembang saat ini memungkinkan adanya diversifikasi produk pangan yang berbasis pada tepung sagu, yaitu bisa dikembangkan mulai dari pembuatan produk tepung sagu komposit dan produk-produk lain yang biasa dikonsumsi oleh masyarakat seperti kerupuk. Pemanfaatan tepung sagu sebagai bahan pengikat pada kerupuk memiliki potensi menjadi komoditas unggulan (Nurfadila dkk, 2015). Sagu sangat potensial dan tersedia dalam jumlah yang banyak.

Kemangi adalah spesies basil yang terbesar di seluruh dunia, baik dalam bentuk segar ataupun untuk produksi minyak esensial. Kemangi merupakan salah satu spesies yang menarik karena aroma dan rasanya, tanaman kemangi mengandung minyak atsiri. Tanaman kemangi dapat dimanfaatkan sebagai obat tradisional, daun kemangi digunakan untuk mengobati demam, peluruh asi dan rasa mual.

Daun kemangi banyak digunakan oleh masyarakat Indonesia sebagai menu lalapan yang wajib ada. Sesuai dengan namanya, daun kemangi apabila disandingkan dengan lalapan lain tercium lebih wangi. Daunnya kecil-kecil dan hampir mirip dengan seledri, namun banyak juga yang tidak menyukai daun kemangi karena rasanya yang getir.

Daun kemangi memiliki khasiat dan manfaat yang luar biasa untuk kesehatan, karena daun kemangi mengandung $\beta$ karoten (provitamin A) dan vitamin C, zat besi, kalsium, dan fosfor. Hal yang membuat daun kemangi luar biasa adalah sifat antioksidan dan sifat antibakterinya. Khasiat daun kemangi tidak dapat dirasakan oleh semua orang karena sebagian orang kurang menyukai kemangi. Tapi akhir-akhir ini, sudah bermunculan inovasi baru cara 
menyajikan sayuran jenis ini agar dapat dikonsumsi oleh semua orang, salah satunya yaitu dengan menambahkan kemangi pada pembuatan kerupuk.

Menurut Anindita, dkk (2016) kerupuk merupakan suatu jenis makanan ringan yang sudah lama dikenal oleh sebagian besar masyarakat Indonesia. Kerupuk bertekstur garing dan dikonsumsi sebagai makanan selingan maupun sebagai variasi dalam lauk pauk. Pada dasarnya, makanan tersebut mudah dijumpai dan dijual dengan harga murah baik dalam bentuk kemasan yang belum digoreng (kerupuk mentah) dan kemasan yang sudah digoreng (kerupuk matang).

Menurut Muliyawan (1991) dalam pembuatan kerupuk diperlukan bahan yang mengandung pati sebagai bahan pengikat agar bahan satu sama lain saling terikat dalam satu adonan yang berguna untuk memperbaiki tekstur. Bahan pengikat yang sering digunakan dalam pembuatan kerupuk adalah bahan yang mengandung karbohidrat seperti tepung terigu, tepung beras, tepung ketan, tepung jagung, tepung tapioka, tepung ubi jalar, dan tepung sagu.

Kerupuk sangat beragam dalam bentuk, ukuran, warna, bau, rasa, kerenyahan, ketebalan, ataupun nilai gizinya. Berdasarkan bahan-bahan pemberi rasa yang digunakan dalam pengolahannya, dikenal kerupuk udang, kerupuk ikan, dan beberapa jenis lainnya. Berdasarkan cara pengolahannya, rupa dan bentuk kerupuk dikenal seperti kerupuk mie, kerupuk kembang dan lain sebagainya. Di samping itu, berdasarkan tempat atau daerah penghasil dikenal kerupuk Sidoarjo, kerupuk Surabaya, dan kerupuk Palembang.

Berdasarkan hal tersebut, maka peneliti mencoba melakukan penelitian yang berjudul "Pengaruh Penambahan Bubur Daun Kemangi (Ocimim basilicum L.) terhadap Kandungan Gizi Kerupuk Sagu“.

\section{TUJUAN PENELITIAN}

Penelitian ini bertujuan sebagai berikut:

1. Untuk mengetahui pengaruh konsentrasi penambahan bubur daun kemangi terhadap kandungan gizi kerupuk sagu.

2. Untuk mengetahui penerimaan panelis terhadap kerupuk sagu dengan konsentrasi penambahan bubur daun kemangi.

\section{METODE PENELITIAN}

Penelitian ini diawali dengan tahap persiapan yang meliputi persiapan seluruh alat dan bahan yang akan digunakan pada pembuatan kerupuk sagu dengan penambahan bubur daun kemangi. Persiapan bahan diawali dengan pemilihan daun kemangi yang berkualitas yaitu dengan ketentuan daun kemangi yang tidak cacat, tidak hancur, dan tidak busuk. Sagu yang digunakan yaitu sagu kering yang diperoleh dengan cara sagu basah dicampur air dengan perbandingan 1:1, kemudian disaring, setelah itu didiamkan selama \pm 1 jam, kemudian dikeringkan menggunakan cabinet dryer pada suhu $60^{\circ} \mathrm{C}$ selama \pm 6 jam, seanjutnya diayak menggunakan ayakan 60 mesh. Uraian prosedur penelitian antara lain adalah :

\section{a. Pengolahan Bubur Daun Kemangi}

Pengolahan bubur daun kemangi melalui beberapa tahap, yaitu :

1) Daun kemangi dibersihkan dan dicuci.

2) Daun kemangi disortasi dengan memilih daun kemangi yang tidak cacat, tidak hancur dan tidak busuk. 
3) Kemudian, daun kemangi ditimbang sebanyak 100 gram

4) Setelah itu, daun kemangi ditambahkan air sebanyak $100 \mathrm{ml}$

5) Daun kemangi kemudian dihaluskan menggunakan blender.

\section{b. Pengolahan Kerupuk Sagu}

Pengolahan kerupuk sagu yang ditambahkan dengan bubur daun kemangi melalui beberapa tahap, yaitu sebagai berikut :

1) Tepung sagu sebanyak 500 gram untuk masing-masing campuran dibagi menjadi dua bagian, yaitu bagian A $(50 \%)$ dan bagian $B(50 \%)$. Bagian A ditambahkan dengan air dengan perbandingan 1:2, dan bumbu kerupuk yaitu garam halus $(1 \%)$, gula (1\%), bawang putih (3\%) yang sudah dihaluskan, natrium bikarbonat (5\%), dan telur 1 butir. Campuran kemudian dimasak sambil diaduk menjadi gel kental.

2) Tepung sagu bagian $B$ dicampur sedikit demi sedikit dengan tepung sagu bagian A dan ditambahkan bubur daun kemangi dengan perlakuan $0 \%, 10 \%, 15 \%$, dan $20 \%$.

3) Adonan dihomogenkan hingga tercampur dengan rata dan tidak lengket di tangan.

4) Adonan kemudian dibentuk menjadi silinder (dodolan) dengan panjang $15 \mathrm{~cm}$ dan diameter $2 \mathrm{~cm}$.

5) Adonan dimasukkan ke dalam plastik lembaran yang telah diberi lubang kecil agar pada saat pengukusan adonan cepat matang.

6) Adonan dikukus pada suhu $\pm 100^{\circ} \mathrm{C}$ selama \pm 1 jam.

7) Adonan yang telah matang kemudian diangin-anginkan selama 30 menit
8) Adonan yang telah matang didinginkan di dalam frezer selama \pm 10 jam sehingga kerupuk mengeras dan mudah dipotong.

9) Kemudian, adonan diiris tipis dengan ketebalan $\pm 1-2 \mathrm{~mm}$ menggunakan alat pengiris.

10) Adonan dikeringkan kembali di room dryer dengan suhu $\pm 50^{\circ} \mathrm{C}$ selama \pm 3 hari.

11) Setelah kering, kerupuk digoreng di dalam minyak panas dengan suhu $150^{\circ} \mathrm{C}$ dalam keadaan terendam selama 10 detik sambil dibalik-balik agar merata.

\section{HASIL DAN PEMBAHASAN}

\section{Kadar Air}

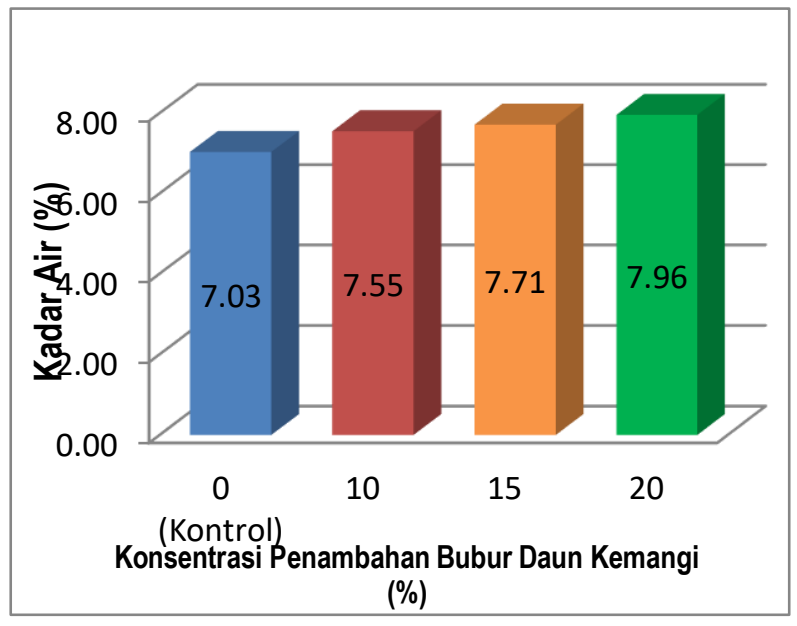

Gambar 1.

Pengaruh Penambahan Konsentrasi Bubur Daun Kemangi terhadap Kadar Air Kerupuk Sagu

Kadar air kerupuk sagu perlakuan penambahan konsentrasi bubur daun kemangi sebanyak 20\% lebih tinggi dibandingkan dengan perlakuan kontrol.

Semakin rendah konsentrasi penambahan bubur daun kemangi, maka kadar air yang dihasilkan juga mengalami penurunan (Irmayanti, dkk 2017). Selain itu, 
penurunan kadar air juga disebabkan oleh adanya penggorengan. Hal ini sesuai dengan pernyataan Weiss (1983) dalam Ratnaningsih, dkk (2007) yang menyatakan dalam penggorengan terjadi perpindahan panas dan massa oleh minyak. Dalam proses penggorengan ini sebagian air dalam bahan pangan akan menguap sehingga menurunkan kadar air yang dihasilkan.

Kadar air kerupuk sagu yang baik adalah perlakuan kontrol dengan nilai kadar air $1,03 \%$, karena semakin rendah kadar air yang dihasilkan maka kerupuk sagu akan semakin bagus. Selain itu, kadar air yang tinggi pada tepung sagu dapat mempengaruhi tekstur yang dihasilkan kerupuk sagu menjadi kurang renyah, sedangkan kadar air yang rendah pada tepung sagu dapat mempengaruhi tekstur kerupuk sagu menjadi renyah. Hilangnya atau kurangnya kandungan air pada sagu basah yang dihasilkan karena pada proses pengolahan sagu basah menjadi tepung telah mengalami proses pengolahan panas yaitu pengeringan dengan menggunakan mesin pengering kabinet sehingga menyebabkan hilangnya air bebas dalam tepung sagu. Hal ini sejalan dengan pendapat Purnomo (1995), bahwa air bebas dapat dengan mudah hilang apabila terjadi penguapan atau pengeringan, sedangkan air terikat sulit dibebaskan dengan cara tersebut.

\section{Kadar Provitamin A ( $\beta$-Karoten)}

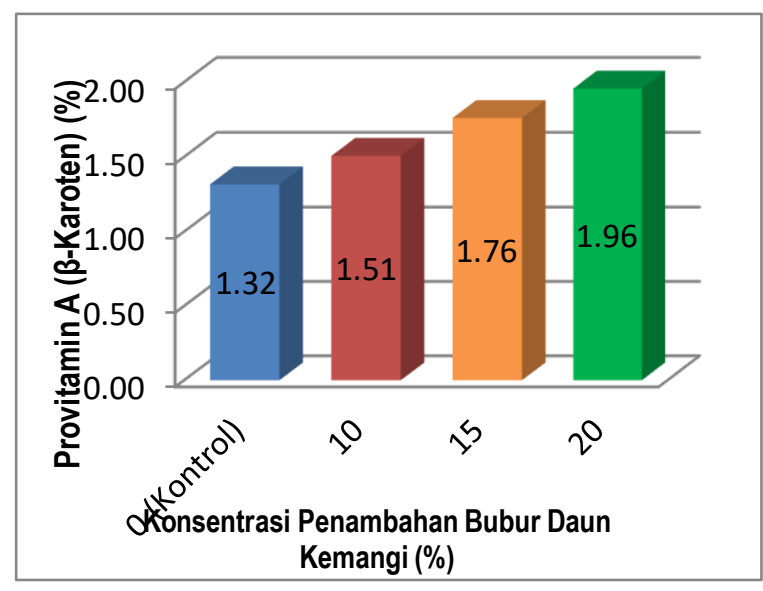

Gambar 2.

Pengaruh Penambahan Konsentrasi Bubur Daun Kemangi terhadap Kadar Provitamin A ( $\beta$ Karoten) Kerupuk Sagu

$$
\text { Hasil menunjukkan adanya }
$$
perbedaan nilai kadar provitamin A ( $\beta$ karoten) akibat pemberian perlakuan konsentrasi pada kerupuk sagu yang dihasilkan. Hal tersebut disebabkan karena semakin banyak konsentrasi penambahan bubur daun kemangi maka kadar provitamin A ( $\beta$-karoten) yang dihasilkan akan semakin tinggi. Menurut Made (2015) kandungan vitamin A daun kemangi tiap 100 gram sebanyak $750 \mathrm{RE}$ (Retinol Equivalents).

Provitamin A ( $\beta$-karoten) kerupuk sagu pada konsentrasi penambahan bubur daun kemangi lebih tinggi dibandingkan dengan kontrol diakibatkan karena daun kemangi kaya akan betakaroten yang berfungsi menajamkan dan mencegah kerusakan mata terutama pada retina mata.

Perlakuan kontrol juga mengandung provitamin A disebabkan oleh adanya bahan tambahan yang digunakan pada pengolahan kerupuk sagu yaitu telur yang mengandung provitamin A sebanyak $900 \mathrm{UI}$. 


\section{Kadar Fosfor}

Hasil penelitian menunjukkan adanya perbedaan kadar fosfor kerupuk sagu pada setiap perlakuan. Kadar fosfor tertinggi diperoleh dari perlakuan penambahan konsentrasi bubur daun kemangi $20 \%$, yaitu $0,045 \%$, sedangkan kadar fosfor yang terendah diperoleh dari perlakuan kontrol, yaitu $0,026 \%$. Hasil penelitian menunjukkan semakin banyak konsentrasi penambahan bubur daun kemangi, yaitu 20\% maka kadar fosfor yang terkandung dalam kerupuk sagu semakin tinggi.

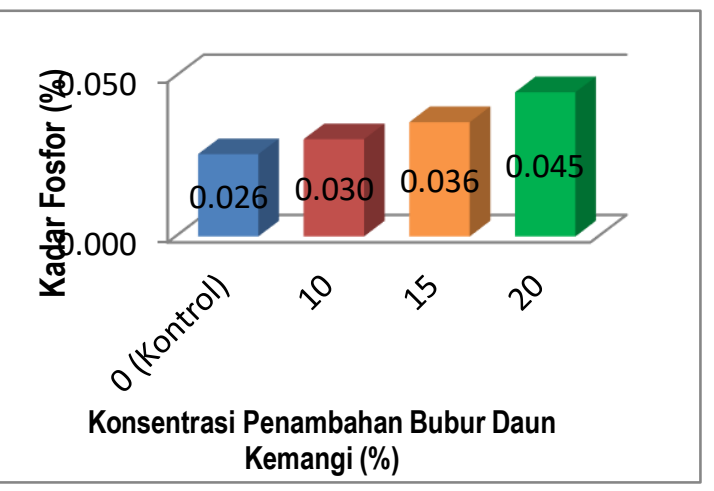

Gambar 3.

Pengaruh Penambahan Konsentrasi Bubur

Daun Kemangi terhadap Kadar Fosfor

Kerupuk Sagu

Kadar fosfor kerupuk sagu tertinggi diperoleh dari konsentrasi penambahan bubur daun kemangi pada perlakuan $20 \%$. Hal tersebut disebabkan karena semakin banyak konsentrasi penambahan bubur daun kemangi maka kadar fosfor yang dihasilkan akan semakin tinggi. Kadar fosfor pada perlakuan kontrol sebesar $0,026 \%$. Fosfor ditemukan dalam kerupuk sagu perakuan kontrol disebabkan oleh bahan tambahan yang digunakan adalah bawang putih, dimana di dalam 100 gram bawang putih mengandung kadar fosfor sebanyak $153 \mathrm{mg}$.

Pentingnya kadar fosfor yang dihasilkan pada kerupuk sagu dengan penambahan bubur daun kemangi karena kebutuhan akan kadar fosfor bagi tubuh manusia terpenuhi tanpa mengkonsumsi secara langsung daun kemangi, melainkan masyarakat dapat menikmatinya dalam bentuk olahan kerupuk.

\section{Kadar Antioksidan}

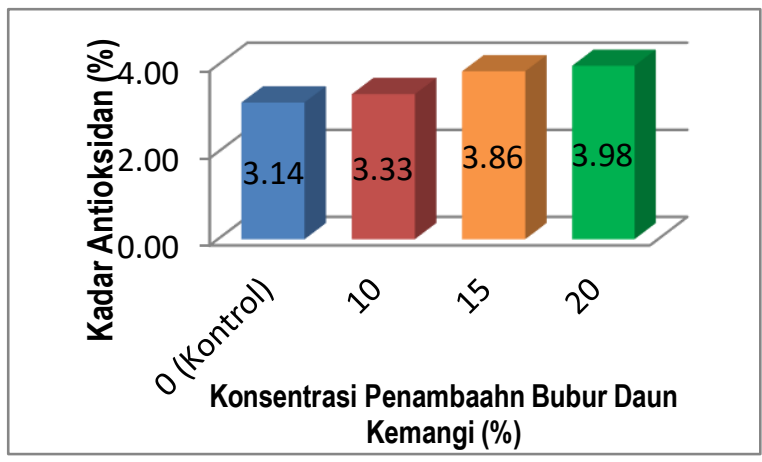

Gambar 4.

Pengaruh Penambahan Konsentrasi Bubur Daun Kemangi terhadap Kadar Antioksidan Kerupuk Sagu

Hasil penelitian menunjukkan semakin banyak konsentrasi penambahan bubur daun kemangi, yaitu 20\% maka kadar antioksidan yang dihasilkan akan semakin tinggi. Hal ini disebabkan karena daun kemangi memiliki antioksidan yang sangat baik untuk melawan radikal bebas yang masuk ke dalam tubuh kita. Kadar antioksidan terdapat juga pada perlakuan kontrol, karena adanya salah satu bahan tambah yang digunakan yaitu telur dan bawang putih, dimana kedua bahan tambah ini juga mengandung antioksidan (Kasmira dkk, 2018).

Daun kemangi mengandung komponen non gizi antara lain senyawa flavonoid dan eugenol, arigin, anetol, boron, 
dan minyak atsiri. Flavonoid dan eugenol berperan sebagai antioksidan, yang dapat menetralkan kolesterol dan bersifat antikanker.

Antioksidan alami di dalam makanan dapat berasal dari senyawa antioksidan yang sudah ada dari satu atau dua komponen makanan, senyawa antioksidan yang terbentuk dari reaksireaksi selama proses pengolahan, senyawa antioksidan yang diisolasi dari sumber alami dan ditambahkan ke makanan sebagai bahan tambahan pangan (Pratt 1992).

\section{Warna}

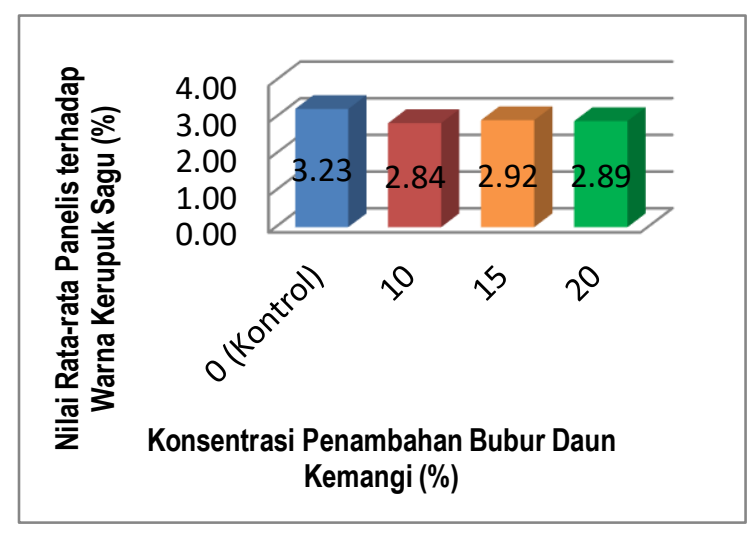

Gambar 5.

Tingkat Kesukaan Panelis Terhadap Warna Keupuk Sagu

Data yang dihasilkan menunjukkan bahwa panelis menyukai perlakuan kontrol dibandingkan warna kerupuk sagu dengan perlakuan konsentrasi penambahan bubur daun kemangi. Hal ini disebabkan karena tanpa adanya penambahan bubur daun kemangi pada pembuatan kerupuk sagu menghasilkan warna asli kerupuk sagu yang berwarna cokelat muda, sedangkan kerupuk sagu dengan penambahan konsentrasi bubur daun kemangi menghasilkan kerupuk sagu berwarna cokelat gelap.

Hal ini diduga karena proses pemasakan dengan panas menyebabkan terjadinya pencoklatan non enzimaztis pada kerupuk sagu. Menurut Vaclavin dan Christian (2007) pencoklatan non enzimatis seperti reaksi Maillard dan karamelisasi ini sering terjadi selama pemanasan. Reaksi Maillard meningkat tajam pada suhu yang tinggi dan menyebabkan pencoklatan semakin cepat terjadi (Winarno, 2002).

Warna alami yang terdapat pada kemangi didapat dari zat hijau daun yaitu klorofil. Winarno (1980), klorofil yang terdapat didalam kloroplas, sel-sel ini akan pecah akibat penggilingan sehingga pigmen akan keluar dan sebagian akan rusak atau teroksidasi karena kontak dengan udara.

Perubahan warna ini juga terjadi karena klorofil memiliki sifat yang tidak stabil sehingga sulit menjaga agar molekulnya tetap utuh, terlebih dengan perlakuan pemanasan. Winarno (1992), menyatakan bahwa klorofil dalam daun yang masih hidup berikatan dengan protein. Dalam proses pemanasan protein akan terdenaturasi dan klorofil dilepaskan.

\section{Aroma}

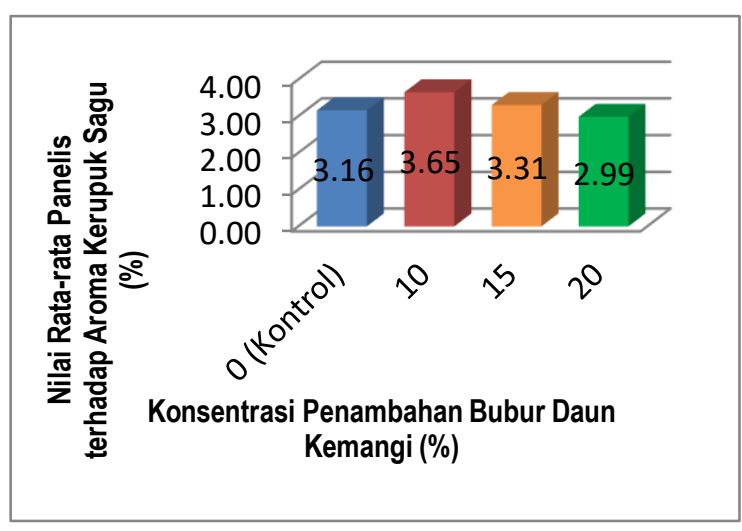

Gambar 5.

Tingkat Kesukaan Panelis Terhadap Aroma Keupuk Sagu

Tingkat kesukaan panelis terhadap aroma kerupuk sagu dipengaruhi oleh penambahan bubur daun kemangi. Semakin 
tinggi konsentrasi penambahan bubur daun kemangi, yaitu 20\% maka aroma yang dihasilkan akan semakin menyengat yang berasal dari kandungan sitral yang tinggi pada daun dan bunganya (Heyne, 1987).

Pengamatan terhadap aroma kerupuk sagu dilakukan dengan cara penentuan tingkat kesukaan aroma secara sensorik dengan indra pembau (Sri, 2017). Tingginya tingkat kesukaan aroma terhadap kerupuk sagu disebabkan oleh adanya penambahan bubur daun kemangi yang memiliki aroma sangat khas yang berasal dari daunnya yang sangat kuat namun lembut dengan sentuhan aroma limau. Bau aromatik yang unik dari daun kemangi juga berasal dari kandungan minyak atsiri yang terkonsentrasi pada daun yang diketahui terdapat bahan utama aktif eugenol sebanyak $71 \%$ yang juga dapat merangsang produksi saliva dengan cara neuronal melalui sistem syaraf autonom, baik simpatis maupun parasimpatis (Shinta, 2012).

\section{Rasa}

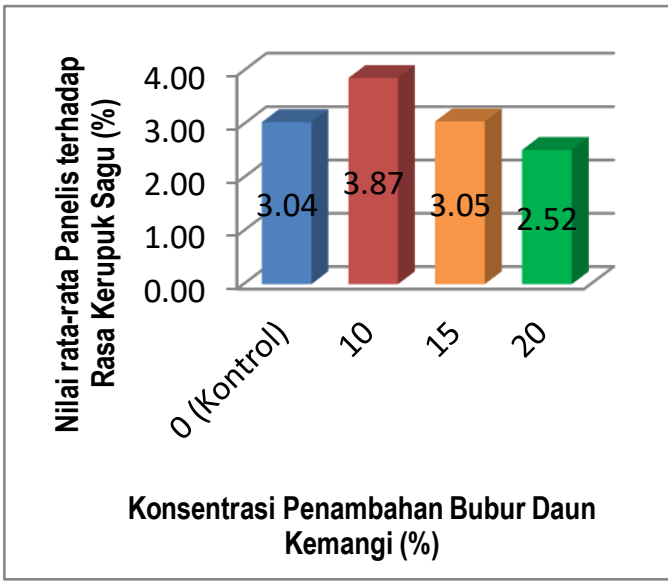

Gambar 5.

Tingkat Kesukaan Panelis Terhadap Rasa Keupuk Sagu

Hasil analisis menunjukkan bahwa perbedaan penambahan bubur daun kemangi pada pembuatan kerupuk sagu berpengaruh terhadap rasa pada kerupuk sagu yang dihasilkan.Hal ini disebabkan karena semakin banyak penambahan bubur daun kemangi maka rasa kerupuk sagu yang dihasilkan akan semakin pahit.

Kandungan flavonoid pada daun kemangi menyebabkan terdapatnya rasa pahit dan kesat pada tumbuhan ini sehingga dapat memacu dan merangsang sekresi kelenjar saliva dalam meningkatkan produksi saliva dengan cara kimiawi. Menurut Teuscher (2006) kemangi mempunyai rasa rempah, terkadang menyerupai merica dan terkadang menyegarkan.

Perbedaan rasa pada daun kemangi dikarenakan oleh beberapa senyawa kimia yang terkandung didalamnya, terutama methyl chavicol (orestragol), linalool, citral, methyl cinnamate, dan euganol (Raghavan, 2000).

\section{Tekstur}

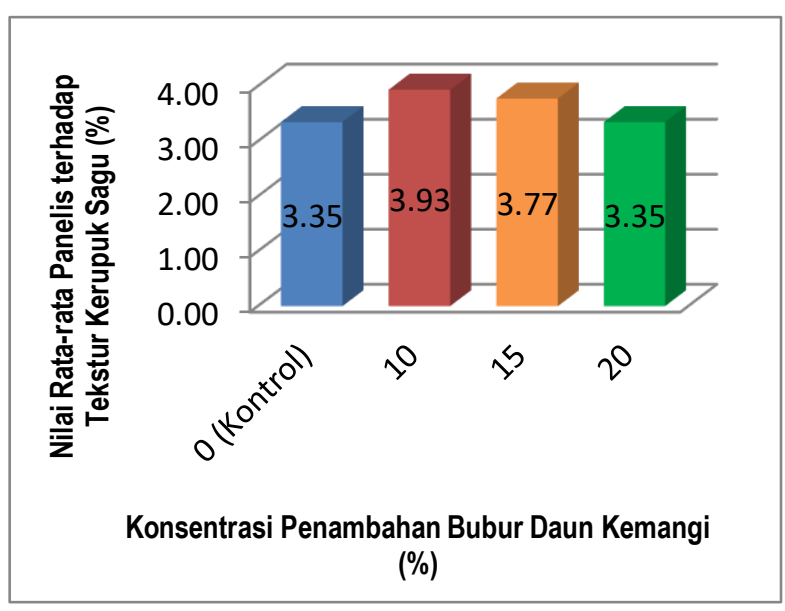

Gambar 5.

Tingkat Kesukaan Panelis Terhadap Tekstur Keupuk Sagu

Skor organoleptik terhadap tekstur kerupuk sagu yang paling disukai oleh panelis diperoleh dari perlakuan konsentrasi 
penambahan bubur daun kemangi sebanyak $10 \%$. Tekstur kerupuk yang dihasilkan renyah, hal tersebut dikarenakan kadar air kerupuk sagu yang dihasilkan tergolong rendah. Kerupuk dibuat dari bahan baku dan bahan tambahan. Sumber bahan baku yang digunakan untuk membuat kerupuk adalah bahan pangan dengan kandungan karbohidrat yang cukup tinggi, yaitu pati. Pati yang digunakan sebagai bahan baku dalam pembuatan kerupuk disebut sebagai puffable material. Puffable material adalah bahan yang memegang peranan utama dalam proses pemekaran produk (Koswara,2009).

\section{KESIMPULAN}

Berdasarkan hasil pembahasan dalam penelitian ini, maka dapat disimpulkan sebagai berikut :

1. Konsentrasi penambahan bubur daun kemangi memberikan pengaruh terhadap kandungan gizi (kadar air, kadar provitamin A ( $\beta$-karoten), kadar fosfor, dan kadar antioksidan) kerupuk sagu yang dihasilkan.

2. Kerupuk sagu dengan konsentrasi penambahan bubur daun kemangi memberikan pengaruh terhadap tingkat penerimaan panelis.

3. Kerupuk sagu terbaik dihasilkan dari perlakuan konsentrasi penambahan bubur daun kemangi sebanyak 10\% dengan kadar air 7.96\%, kadar provitamin A ( $\beta$-karoten) 1,96\%, kadar fosfor $0,045 \%$, dan kadar antioksidan $3,98 \%$, dan nilai uji organoleptik berada pada kisaran suka.

\section{DAFTAR PUSTAKA}

Alfons, J. B dan Bustaman, S., 2005. Prospek dan Arah Pengembangan Sagu di Maluku. Balai Pengkajian
Teknologi Pertanian Maluku. Badan Litbang Pertanian, Maluku.

Auliah, A. 2012. Formulasi Kombinasi Tepung Sagu dan Jagung pada Pembuatan Mie. Jurnal Chemica Vol. 13 No. 2 Hal. 33 -38.

Boston. 2009. Proses Pengolahan Sagu. Diakses 06 Oktober 2016.

Heyne, K. 1987. Tumbuhan Berguna Indonesia Jilid II. Badan Litbang Kehutanan, Jakarta.

Irmayanti, Husain Syam, dan Jamaluddin. 2017. Perubahan Tekstur Kerupuk Berpati Akibat Suhu dan Lama Penyangraian. Jurnal Pendidikan Teknologi Pertanian. Vol.3 (2017): S165-S174. FT.UNM.

Kasmira, Lahming, dan Ratnawaty Fadilah. 2018. Analisis Perubahan Komponen Kimia Keripik Bayam Hijau (Amaranthus tricolor. L) Akibat Proses Penggorengan. Jurnal Pendidikan Teknologi Pertanian. Vol.4 (2018): S49-S55. FT.UNM.

Koswara, Sutrisno. 2009. Sagu Sebagai Bahan Pangan. www. ebookpangan. com. Diakses 17 Agustus 2016.

Made Astawan. 2015. Kandungan Gizi Daun Kemangi. Institut Pertanian Bogor. Bogor

Muliyawan, D. 1991. Pengaruh Berbagai Tingkat Kadar Air Terhadap Pengembangan Kerupuk Sagu Goreng. Skripsi. Jurnal teknologi industry, FATETA, IPB, Bogor.

PKPP. 2012. Peningkatan Nilai Tambah Sagu Dalam Pengembangan Usaha Rumah Tangga Di Provinsi 
Gorontalo. Balai Peningkatan Kemampuan Peneliti dan Perekayasa Provinsi Gorontalo. http://pkpp.ristek.go.id/index.php/pe nelitian/ detail/748. [20 April 2014]

Pratt 1992. Antioksidan alami pada bahan pangan. Poltekkes Kemenkes Jakarta II

Purnomo, 1995. Aktivitas Air dan Peranannya dalam Pengawetan Pangan. Jakarta:Universitas Indonesia.

Raghavan, Susheela. 2000. A Handbook of Spices, Seasonings, and Flavorings. Technomic Publishing Company, Inc. United States of America.

Ratnaningsih, B. Raharjo dan Suhargo, 2007. Kajian Penguapan Air dan Penyerapan Minyak pada Penggorengan Ubi Jalar (Ipomoea batatas L.) dengan metode deep-fat frying. Agritech 27:28-29

Richana, N., P. Lestari, N. Chilmijati, dan S. Widowati. 2000. Karakterisasi Bahan Berpati (Tapioka, Garut dan Sagu) dan Pemanfaatannya Menjadi Glukosa Cair. Prosiding Seminar Nasional Industri Pangan. Volume I. PATPI, Surabaya. Hal. 396-406

Rusman, AR., Kadirman, dan Wiharto Caronge. 2016. Pengembangan Produk Kerupuk Udang Melalui Subtitusi Tepung Ubi Jalar Ungu (Ipomoea batatas Lam) dengan Variasi Lama Penggorengan. Jurnal Pendidikan Teknologi Pertanian. Vol.2 (2016): 135-148. FT.UNM.
Shinta., 2012, Potensi Minyak Atsiri Daun Nilam (Pogostemon cablin B.), Daun Babadotan (Ageratum conyzoides $L$ ), Bunga Kenanga (Cananga odorata hook $F$ \& Thoms) dan Daun Rosemary (Rosmarinus officinalis L) Sebagai Repelan Terhadap Nyamuk Aedes aegypti L, Media Litbang Kesehatan., 22(2): 61-69.

Syamsuddin,N., Kadirman, dan Wiharto Caronge. 2015. Analisis Kesukaan terhadap Karakteristik Olahan Nugget yang Disubtitusi Rumput Laut dan Tepung Sagu. Jurnal Pendidikan Teknologi Pertanian. Vol.1 (2015): 1-11. FT.UNM.

Teuscher, Eberhard. 2006. Medicinal Spices : A Handbook of Culinary Herbs, Spices, Spice Mixtures and Their Essential Oils. Medpharm Scientific Publishers Stuttgart. Germany.

Vaclavik, V dan Christian, E.W. 2007. Essentials of Food Science. Springer. New York

Wahyuni,S., M. Rais, dan Ratnawaty Fadiah. 2017. Fortifikasi Tepung Kulit Melinjo sebagai Pewarna Alami pada Pembuatan Kerupuk Singkong. Jurna Pendidikan Teknoogi Pertanian. Vol. 3 (2017): 212-222.FT. UNM.

Winarno, G., S. Fardiaz, dan D. Fardiaz. 1980. Pengantar Teknologi Pangan. Penerbit PT. Gramedia. Jakarta.

Winarno F, G. 1980. Kimia Pangan dan Gizi II. Jakarta: PT. Gramedia. 
Winarno, F.G. 2002. Kimia Pangan dan Gizi.

PT. Gramedia Pustaka Utama.

Jakarta. 